Ніколюк О.В.

доктор економічних наук, професор кафедра менеджменту та логістики

Email: alenavn11@gmail.com

ORCID ID: 0000-0002-1665-0361
Бондар В.A.

кандидат економічних наук, старший викладач кафредра менеджменту та логістики

E-mail: bondarv1801@gmail.com

ORCID ID: 0000-0002-0419-6579

\author{
Цвєткова Н.Ю. \\ магістрант \\ кафедра менеджменту та логістики \\ Одеська національна академія харчових технологій \\ вул. Канатна 112, м. Одеса, Україна, 65039 \\ E-mail: tsvetkova_nadin@ukr.net \\ ORCID ID: 0000-0003-3372-3654
}

\title{
НАПРЯМИ УДОСКОНАЛЕННЯ СИСТЕМИ ПУБЛІЧНОГО УПРАВЛІННЯ РОЗВИТКОМ У СФЕРІ ОХОРОНИ ЗДОРОВ'Я УКРАЇНИ
}

У статті обґрунтовано напрями удосконалення системи публічного управління розвитком сфери охорони здоров'я України. Визначено, що перспективним напрямком вдосконалення системи публічного управління розвитком сфери охорони здоров'я $€$ використання механізму державноприватного партнерства. Запровадження ефективних інститутів взаємодії держави і приватного сектору сприяє розподілу повноважень на право власності, засоби виробництва й сприятиме розвитку сфери охорони здоров'я України. Метою трансформації системи публічного управління розвитком у сфрері охорони здоров'я варто вважати, перш за все, становлення ефективних механізмів публічного управління якості надаваної медичної допомоги, шляхом проведення системної перебудови такої галузі, фрормування комплексного нормативно-правового простору й інформаційно-методологічної доктрини щодо розвитку сфери охорони здоров'я. Формування протоколів щодо надання медичної допомоги повинно проводитись Міністерством охорони здоров'я разом із Академією медичних наук України та із залученням до їх опрацювання провідних експертів, науково-дослідних установ тощо. Обґрунтовано актуальність та перспективність фрормування єдиної публічної системи стандартизації в сорері охорони здоров'я, яка має орієнтуватись на: забезпечення її цілісності шляхом імплементації єдиних підходів до проведення нормування, акредитації, ліцензування та сертифікації; сприяти підвищенню якості, доступності і безпеки медичних послуг, лікарських засобів та різних виробів медичного призначення; оптимальне й результативне використання фрінансових, кадрових та матеріальних ресурсів; динамічність впровадження інноваційних медичних технологій та інформаційних технологій; інтеграцію сфери охорони здоров'я України у глобальне медичне співтовариство.

Ключові слова: управління, публічне управління, сфрера охорони здоров'я, розвиток, державно-приватне партнерство.

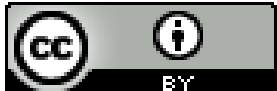

This work is licensed under a Creative Commons Attribution 4.0 International License http://creativecommons.org/licenses/by/4.0/

Постановка проблеми та ї̈ зв'язок 3 важливими науковими та практичними завданнями. В умовах стрімкої глобалізації та європейської інтеграції економіки України зростає потреба здійснення нової політики публічного управління у сфері охорони здоров'я, результати функціонування якої насамперед впливають на розвиток країни загалом та соціальну безпеку зокрема. Базисом сучасної соціальної парадигми повинно бути розуміння того, що саме охорона здоров'я $є$ не лише зобов'язанням кожної держави перед населенням щодо забезпечення доступності та якості медичних послуг, а й важливим перспективним видом реалізації економічної діяльності. Тому актуальності набувають питання трансформації такої діяльності із соціально-витратної на ефективну соціально-інвестиційну, тобто інвестиції в людину, в iï соціальний потенціал мають принципово важливе значення, слугуючи соціальним капіталом й фундаментом для економічного i політичного розвитку України. Необхідність проведення трансформацій системи публічного управління у сфері охорони здоров'я України зумовлено насамперед реальними суспільно-політичними й економічними процесами. 
Аналіз останніх публікацій по проблемі. Теоретико-прикладні засади щодо розвитку сфери охорони здоров'я та його публічного управління вивчають як закордонні, так й вітчизняні науковці. Вагомий внесок у вирішення досліджуваних питань здійснили вітчизняні і зарубіжні науковці, серед яких: А. Абрамешин, О. Амоша, Ю. Анісімов, І. Борисенко, А. Бронштейн, В. Воронін, А. Вялков, Н. Герасименко, Н. Грищенко, І. Гладун, П. Друкер, В. Жаріков, Ф. Кадиров, Д. Карамишев, Р. Портер, Ю. Саліков, Г. Слабкий, Дж. Стігліц, І. Шейман, В. Шевський, Й. Шумпетер, Л. Якобсон та ін. Водночас нині ще не набули цілісного відображення підходи до реформування системи публічного управління розвитком сфери охорони здоров'я, актуальними залишаються також питання розробки концептуальних положень взаємної узгодженості соціально-економічних інтересів стейкхолдерів системи публічного управління розвитком сфери охорони здоров'я України й інструментарію публічного управління.

Формулювання цілей дослідження. Метою статті $€$ теоретико-методологічне обгрунтування напрямів удосконалення системи публічного управління розвитком сфери охорони здоров'я України.

Виклад основних результатів та їх обгрунтування. Сфера охорони здоров'я як соціальна система не повинна існувати в умовах прямої конкуренції між виробниками медичних послуг. Однак конкуренція є двигуном прогресу, тому елементи конкуренції все ж таки мають бути присутні. Це, перш за все, публічність звітів про результати діяльності різних закладів охорони здоров'я із можливістю проведення незалежної оцінки такої діяльності, тобто йдеться саме про конкуренцію в інформаційному просторі, що безпосередньо не стосується питань фінансового блоку. Це також може опосередковано свідчити про рівень якості надання медичної допомоги у таких закладах. Що ж стосується надання немедичних послуг, які також мають вплив на якість життя пацієнтів й загалом на перебіг захворювання, то тут актуальним $\epsilon$ широке використання міжнародного досвіду запровадження аутсорсингу як дієвого важеля впливу на рівень якості медичного обслуговування.

Сформовані ринкові відносини в сфері охорони здоров'я не варто вводити доти, поки не буде врегульовано питання подолання асиметрії інформації для конкретних одержувачів медичної допомоги та медичних послуг, внаслідок відсутності механізму захисту пацієнта від різного роду монопольного та необумовленого права лікаря призначати відповідні форми обстеження і лікування, іншими словами, від так званого недобросовісного нав'язування лікарем необгрунтованих медичних послуг. Тому варто створити спеціальні консалтингові і арбітражні служби, куди б могли безпосередньо звертатися пацієнти. Однак, перш за все, необхідно розробити стандарти щодо надання лікувально-діагностичної допомоги, однак це лише теоретично. Практично, зробити це досить складно, скоріше неможливо - як неможливо обмежити надання медичної допомоги певними межами.
Адже медицина - це ще й мистецтво, й тут точні науки не допоможуть, бо визначальну роль відіграють сам такі фактори, як досвід, самовідданість й інтуїція лікаря-фахівця.

Таким чином, по-перше, асиметрія інформації в сфері охорони здоров'я, й по-друге - стрімкий розвиток сучасних інформаційних технологій і необхідність упровадження їх у діяльність закладів охорони здоров'я потребує вдосконалення й посилення інформаційної ланки публічного управління в сфері охорони здоров'я. Такою ланкою можуть бути інформаційно-аналітичні центри, які мають замінити служби медичної статистики, які вже практично втратили свою актуальність, адже відповідали лише за збір, обробку й збереження медичної інформації, залишаючись практично технічними ланками в сфері охорони здоров'я.

Отже, якісна складова реалізації публічної політики у сфері охорони здоров'я передбачає сукупність інноваційних трансформацій, які повинні стосуватися не лише модернізації існуючої матеріальнотехнічної бази даної галузі, упровадження інноваційних прогресивних засобів й методів лікування, а й бути орієнтованими на вдосконалення діючої нормативно-правової бази, встановлення гарантованого державою обсягу безоплатної медичної допомоги, поступовий перехід до переважно бюджетнострахової форми проведення організації сфери охорони здоров'я, адаптація стандартів медичних технологій до міжнародних стандартів, на досягнення справедливості та рівності в питаннях забезпечення охорони здоров'я, подолання асиметричності інформації між різними суб'єктами в сфері, розробки сучасної інфраструктури, яка б відповідала сучасним умовам функціонування сфери охорони здоров'я в сучасних умовах [1,2].

Перспективним напрямком вдосконалення системи публічного управління розвитком сфери охорони здоров'я є використання механізму державно-приватного партнерства. Запровадження ефективних інститутів взаємодії держави і приватного сектору сприяє розподілу повноважень на право власності, засоби виробництва й сприятиме розвитку сфери охорони здоров'я України (рис.1). За отриманими даними проведеного аналізу використання форм державно-приватного партнерства у різних галузях України, зауважимо, що найбільш дієвими у вітчизняних реаліях є використання двох таких моделей співробітництва: концесійна, у вигляді угоди (тобто зберігається право державної власності на відповідний об'єкт), й приватна власність на об'єкт.

Базисом управління соціально-економічними системами, якою є безпосередньо сфера охорони здоров'я, є виважене стратегічне управління розвитком. Зростання рівня підзвітності, прозорості - $є$ тими факторами, які зорієнтовані на покращення роботи сфери охорони здоров'я. Враховуючи вищезазначене, нами запропоновано такі перспективні напрями вдосконалення системи публічного управління розвитком сфери охорони здоров’я (табл. 1). 


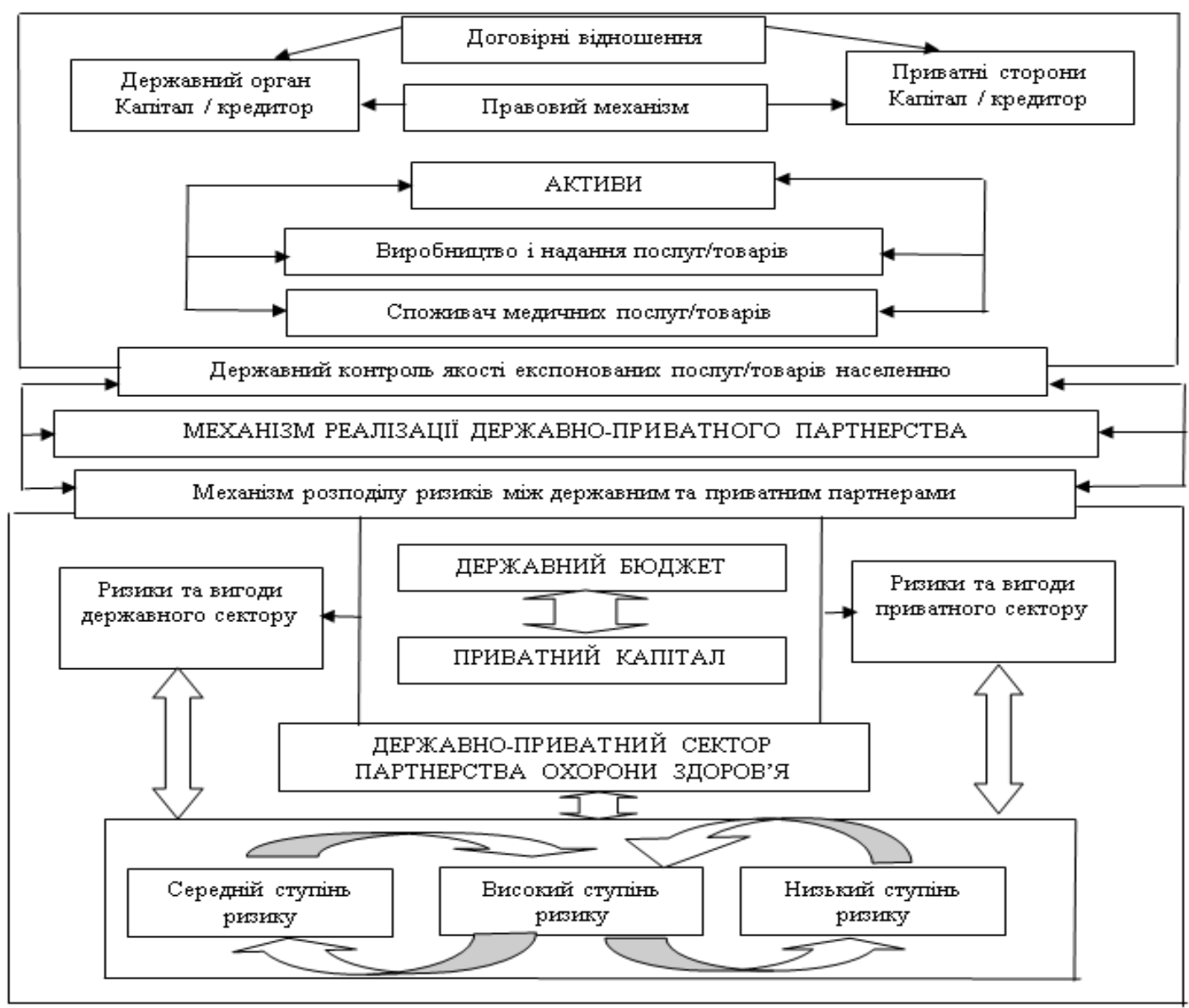

Рис. 1. Механізм реалізації державно-приватного партнерства у сфері охорони здоров'я *побудовано автором

Одними із дієвих засобів публічного управління розвитком сфери охорони здоров'я в Україні можуть стати державні соціальні стандарти, норми й нормативи, які використовуються як важливий еле- мент при розробці поточних й перспективних планів досліджуваної сфери, а також при обгрунтуванні моделей розвитку сфери охорони здоров'я.

Таблиця 1

Рекомендації для вдосконалення системи публічного управління розвитком сфери охорони здоров'я*

\begin{tabular}{|c|c|}
\hline Критерії & Перелік рекомендацій \\
\hline $\begin{array}{l}\text { Реалізація соціальних напря- } \\
\text { мів інноваційних трансфор- } \\
\text { мацій в організаційній пло- } \\
\text { щині суб'єктів господарюван- } \\
\text { ня сфери охорони здоров’я } \\
\text { загалом }\end{array}$ & $\begin{array}{l}\text { - модернізація матеріально-технічної бази; } \\
\text { - впровадження інновацій у сфері охорони здоров’я: нових методичних те- } \\
\text { хнологій, прогресивних засобів і методів лікування; } \\
\text { - встановлення гарантованого державного обсягу безоплатної методичної } \\
\text { допомоги та запровадження багатоканального фінансування; } \\
\text { - розроблення програмних засобів опрацювання інформації, удосконалення } \\
\text { існуючих методів діагностики та лікування й модернізації технологічних } \\
\text { процесів, освоєння нового обладнання, впровадження нових технологій, а } \\
\text { також реформування сфери управління охороною здоров’я шляхом ство- } \\
\text { рення нових моделей функціонування цієї сфери і відповідної підготовки та } \\
\text { перепідготовки кадрів. }\end{array}$ \\
\hline $\begin{array}{l}\text { Вдосконалення нормативно- } \\
\text { правового поля }\end{array}$ & $\begin{array}{l}\text { - покращення нормативно-правового законодавства, а саме у частині захис- } \\
\text { ту авторського соціальних напрямів інноваційної діяльності в фармацевтич- } \\
\text { ній сфері та сфері охорони здоров’я, правової легалізації; } \\
\text { - взаємообумовлена підготовка міжнародних норм та стандартів; } \\
\text { - сертифікація лікувальних засобів згідно з стандартами GMP, підтверджен- } \\
\text { ня належного рівня якості, ефективності , результативності, різного виду } \\
\text { безпеки інноваційного продукту. }\end{array}$ \\
\hline
\end{tabular}


Продовження табл.1

\begin{tabular}{|c|c|}
\hline Критерії & Перелік рекомендацій \\
\hline $\begin{array}{l}\text { Впровадження заходів у нор- } \\
\text { мативно-виробничій площині } \\
\text { щодо розвитку фармацевтич- } \\
\text { ного сегменту та сфери охо- } \\
\text { рони здоров’я }\end{array}$ & $\begin{array}{l}\text { - враховуючи соціальне навантаження, неефективність загальних принципів } \\
\text { стимулювання інноваційної діяльності, доцільно: } \\
\text { - створювати венчурні фонди за участю держави з метою постійного та ква- } \\
\text { ліфікованого контролю за виконанням інноваційних проєктів та фінансу- } \\
\text { вання національних програм зі створення нових інноваційних лікарських } \\
\text { засобів, медичної техніки та виробів медичного призначення тощо; } \\
\text { - створити Національну лізингову компанію, якій надати повноваження } \\
\text { пільгової закупівлі медичної техніки, обладнання та устаткування і право } \\
\text { визначення науково-експертних центрів щодо експертизи виробів медично- } \\
\text { го призначення, що підлягають внесенню до Державного реєстру. }\end{array}$ \\
\hline
\end{tabular}

*Побудовано автором

До державних соціальних нормативів у сфері охорони здоров'я належать: перелік і обсяг гарантованого рівня медичної допомоги громадянам у державних й комунальних закладах охорони здоров'я; надання медичної допомоги (обсяг діагностичних, лікувальних і профілактичних процедур тощо); показники якості надання медичної допомоги; пільгове забезпечення окремих категорій населення лікарськими засобами та іншими спеціальними засобами; забезпечення стаціонарною медичною допомогою; забезпечення медикаментами державних і комунальних закладів охорони здоров'я; забезпечення харчуванням у державних і комунальних закладах охорони здоров'я $[3,4]$.

У сучасних соціально-економічних умовах упровадження медичної стандартизації розглядається як один із пріоритетних напрямів щодо формування й реалізації системи публічного управління у сфері охорони здоров'я. Створення єдиної сфери стандартизації в охороні здоров'я орієнтовано на: забезпе-

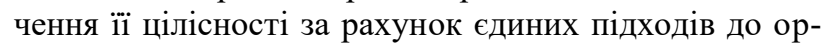
ганізації нормування, акредитації, ліцензування й сертифікації; удосконалення управління галуззю, підвищення якості і безпеки медичної допомоги, лікарських засобів та виробів медичного призначення; раціональне використання відповідних фінансових, кадрових й матеріальних ресурсів; прискорення впровадження нових медичних технологій; інтеграцію вітчизняної охорони здоров'я у глобалізовану медичну спільноту.

Розвитку системи стандартизації в охороні здоров'я України передували: динамічний розвиток й вдосконалення медичних технологій; поява дієвих високоефективних лікарських засобів й складність їхнього вибору через диверсифікованість альтернатив; відсутність погодженості проведення оцінки ефективності методик, алгоритму ведення пацієнтів із однаковою патологією; наростання потреби в медичній допомозі у зв'язку із постійним старінням населення; випадки нераціонального використання існуючих ресурсів; недостатнє фінансове забезпечення різних потреб охорони здоров'я; потреба у використанні сфери доказів результативності, безпеки й економічної доцільності; актуальність визначення обсягів гарантованого державою належного рівня безоплатної медичної допомоги; стратегічні перспективи впровадження соціального медичного страхування тощо $[5,6]$.

Метою трансформації системи публічного управління розвитком у сфері охорони здоров'я варто вважати, перш за все, становлення ефективних механізмів публічного управління якості надаваної медичної допомоги, шляхом проведення системної перебудови такої галузі, формування комплексного нормативно-правового простору й інформаційнометодологічної доктрини щодо розвитку сфери охорони здоров'я. Формування протоколів щодо надання медичної допомоги повинно проводитись Міністерством охорони здоров'я разом із Академією медичних наук України та із залученням до їх опрацювання провідних експертів, науково-дослідних установ тощо.

Сьогодні прийняття виважених публічних управлінських рішень у сфері охорони здоров'я повинні враховувати вимоги доказової медицини. Науково обгрунтована практика - це своєрідна спроба змінити сферу авторитарних зв'язків у медицині, що існує досить давно, коли за основу прийняття виважених управлінських рішень, на жаль, береться стійка традиція або думка авторитета $[7,8]$.

Таким чином, першочерговим завданням публічного управління розвитком сфери охорони здоров'я $\epsilon$ створення законодавчої інформативноправової бази щодо стандартизації: проекту Закону України “Про стандартизацію в охороні здоров'я" i програми робіт із розвитку стандартизації. Така програма повинна вдосконалити підходи до управління в сфері охорони здоров'я, забезпечення ії комплементарності за рахунок єдиних підходів до організації планування, нормування, проведення ліцензування й сертифікації, сприяння підвищення ефективності функціонування сфери охорони здоров'я, орієнтованої на вирішення завдань із збереження й покращання здоров’я населення, динамічного прискорення інтеграції України до ЄС й інших міжнародних структур.

Таким чином, позитивними результатами від реалізації системи стандартизації в охороні здоров'я повинні стати: створення публічної сфери для стандартизації в охороні здоров'я; використання підходів до стратегічного планування діяльності, управління i контроль витрат, підвищення індикаторів результативності діяльності закладів охорони здоров'я; 
зростання якості і безпеки медичних послуг, відповідних лікарських засобів й виробів медичного призначення; динамічне прискорення впровадження інноваційних медичних технологій; підвищення показників здоров'я населення; прискорення вступу України до міжнародних структур. Таким чином, прийняття та реалізація представленої нами Програми дозволить удосконалити нормативно-правову базу щодо стандартизації, запровадити нові прогресивні технології, а також загалом сфери управління якістю медичної допомоги й здійснювати іiї державну підтримку, суттєво задовольнити попит населення на безпечну і якісну медичну допомогу

Висновки та перспективи подальших досліджень. Виваженими стратегічними пріоритетами системи публічного управління розвитком сфери охорони здоров'я України є формування й втілення завдань орієнтованих на впровадження науковотехнічних інновацій, постійне стимулювання попиту на наукові дослідження у сфері охорони здоров'я, поступове налагодження міжнародної співпраці, динамічний розвиток форм державно-приватного партнерства й інноваційних центрів. Враховуючи міжгалузевий характер публічного управління розвитком сфери охорони здоров'я, актуальним є становлення окремого координаційного органу 3 публічного управління розвитком при об'єднаних територіальних громадах або ж закріплення чітких функцій до вже функціонуючих інституцій сфери охорони здоров'я, які повинні ефективно виконувати такі завдання: проведення аналізу реального стану й тенденцій розвитку сфери охорони здоров'я, оцінку перспектив розвитку; організацію й координацію діяльності із законодавчого забезпечення розвитку, насамперед, розгляд питань щодо надання різних пільг й преференцій інвесторам пріоритетних проектів розвитку; визначення пріоритетних інноваційних проектів i ïx моніторинг; опрацювання заходів щодо фінансового, матеріально-технічного, ресурсного й кадрового забезпечення реалізації проектів розвитку тощо.

Отже, перспективним напрямом удосконалення системи управління розвитком сфери охорони здоров'я $€$ створення міжгалузевих наукововиробничих комплексів як важливої складової частини єдиної мезосистеми, які певним чином поєднують провідні науково-дослідні установи, різні кредитнофінансові установи, можливі фонди розвитку, навчальні заклади, венчурні підприємства, страхові компанії, консалтингові, інжинірингові, сертифікаційні й маркетингові фірми, інформаційно-консультаційні центри. Таким чином, за допомогою функціонування таких центрів можливим стає становлення більш матричної системи публічного управління розвитком сфери охорони здоров'я, що насамперед передбачає прийняття рішень й функціонування сфери загалом по горизонталі, яка $є$ досить гнучкою системою, яка схильна до трансформацій.

\section{Література}

1. Бержанір А.Л. Світовий досвід забезпечення взаємодії влади та бізнесу в економічних системах // Вісник Донецького національного університету. Вінниця. 2015. № 1. С. 32-35.

2. Гураль П.Ф. Громадянське суспільство і держава в Україні: взаємодія і розвиток // Часопис Київського університету права. 2013. № 3. С. 13-16.

3. Голуб В.Л. Державне визнання волонтерської діяльності як чинник розвитку взаємовідносин держави та суспільства // Теорія та практика державного управління. 2014. Вип. 4 (47). С. 110-118.

4. Державна політика розвитку громадянського суспільства: моніторинг ефективності. Європейський досвід. К.: ПРООН, 2011.97 с.

5. Ладиченко В. Проблеми взаємодії держави і громадянського суспільства // Публічне право. 2016. № 4 (24). С. $18-25$.

6. Майсара Алкум. Міжнародний досвід організації конструктивного діалогу між організаціями громадянського суспільства та державними органами // Інвестиції: практика та досвід. 2018. № 11. С. 134-137.

7. Матійчик А.В. Волонтерська діяльність як детермінанта розвитку громадянського суспільства // Науково-теоретичний і громадсько-політичний альманах «Грані». 2016. Вип. 8 (136). С. $100-107$. doi.org/10.15421/171658

8. Schorpp R. Greece \& Germany: What Role for Civil Society? Workshop III of the Greek-German Youth Congress; Political foundation "The Konrad-Adenauer-Stiftung". 2016. 21.01. URL: http://www.kas.de/wf/en/33.35961 (retrieved from: 25.07.2021p.)

9. Briushkova N.O., Nikoliuk O.V., Dobrianska N.A. Institutionalization of the relationship between government and civil society in the context of management decisions // Економіка: реалії часу. Науковий журнал. 2021. № 1 (53). C. 20-26. URL: https://economics.opu.ua/files/archive/2021/No1/20.pdf. DOI: 10.5281/zenodo.4885297. (retrieved from: $25.07 .2021 \mathrm{p}$.)

10. Брюшкова Н.О., Ніколюк О.В., Удовиця О.Ф. Особливості прийняття управлінських рішень в публічному управлінні // Державне управління: удосконалення та розвиток. 2020. № 3. URL: http://www.dy.nayka.com.ua/?op=1\&z=1605. DOI: 10.32702/2307-2156-2020.3.39 (дата звернення: 25.07.2021p.) 


\author{
Nikoliuk 0. \\ Doctor of Economics, Professor \\ Department of Management and Logistics \\ E-mail: alenavn11@gmail.com \\ ORCID ID: 0000-0002-1665-0361 \\ Tsvetkova N. \\ Undergraduate \\ Department of Management and Logistics \\ Odessa National Academy of Food Technologies \\ Kanatna str., 112 Odesa, Ukraine, 65039 \\ E-mail: tsvetkova_nadin@ukr.net \\ ORCID ID: 0000-0003-3372-3654
}

\author{
Bondar V. \\ PhD., Assistant \\ Department of Management and Logistics \\ E-mail: bondarv1801@gmail.com \\ ORCID ID: 0000-0002-0419-6579
}

\section{DIRECTIONS OF IMPROVEMENT OF THE SYSTEM OF PUBLIC MANAGEMENT IN HEALTHCARE DEVELOPMENT OF UKRAINE}

The article substantiates the directions of improving the system of public management of health care development in Ukraine. It has been determined that the promising direction of improving the system of public management of health care development is the use of public-private partnership mechanism. The introduction of effective institutions of interaction between the state and the private sector promotes the division of powers over property rights, means of production and will contribute to the development of health care in Ukraine. The purpose of transformation of the system of public management of development in the field of health care should be considered, first of all, formation of effective mechanisms of public management of quality of the rendered medical care, by carrying out systematic reorganization of such branch, formation of complex normative-legal space and information-methodological doctrine on development of Health Care. The formation of protocols for the provision of medical care should be carried out by the Ministry of Health together with the Academy of Medical Sciences of Ukraine and with the involvement of leading experts, research institutions, etc. in their development. The relevance and prospects of forming a single public system of standardization in the field of health care, which should focus on: ensuring its integrity through the implementation of common approaches to regulation, accreditation, licensing and certification; to promote the quality, availability and safety of medical services, medicines and various medical devices; optimal and effective use of financial, human and material resources; dynamics of introduction of innovative medical technologies and information technologies; integration of the healthcare sector of Ukraine into the global medical community. A promising area for improving the management system of health care development is the creation of interpectoral research and production complexes as an important part of a single mesosystem, which in some way combine leading research institutions, various credit and financial institutions, possible development funds, schools, ventures, insurance companies, consulting, engineering, certification and marketing firms, information and consulting centers. Thus, with the help of such centers, it is possible to create a more matrix system of public management of health care development, which primarily involves decision-making and the functioning of the sphere as a whole horizontally, which is quite flexible and prone to transformation. partnership.

Key words: management, public administration, health care, development, public-private

\section{References}

1. Berzhanir, A. L. (2015). Svitovyi dosvid zabezpechennia vzaiemodii vlady ta biznesu v ekonomichnykh systemakh. Visnyk Donetskoho natsionalnoho universytetu, (1), 32-35.

2. Hural, P. F. (2013). Hromadianske suspilstvo i derzhava v Ukraini: vzaiemodiia i rozvytok. Chasopys Kyivskoho universytetu prava, (3), 13-16.

3. Holub, V. L. (2014). Derzhavne vyznannia volonterskoi diialnosti yak chynnyk rozvytku vzaiemovidnosyn derzhavy ta suspilstva. Teoriia ta praktyka derzhavnoho upravlinnia, (4 (47)), 110-118.

4. PROON. (2011). Derzhavna polityka rozvytku hromadianskoho suspilstva: monitorynh efektyvnosti. Yevropeiskyi dosvid. (24)), $18-25$

5. Ladychenko, V. (2016). Problemy vzaiemodii derzhavy i hromadianskoho suspilstva. Publichne pravo, (4

6. Maisara Alkum (2018). Mizhnarodnyi dosvid orhanizatsii konstruktyvnoho dialohu mizh orhanizatsiiamy hromadianskoho suspilstva ta derzhavnymy orhanamy. Investytsii: praktyka ta dosvid, (11), 134-137.

7. Matiichyk, A. V. (2016). Volonterska diialnist yak determinanta rozvytku hromadianskoho suspilstva. Naukovo-teoretychnyi i hromadsko-politychnyi almanakh «Hrani», (8 (136)), 100-107. doi.org/10.15421/171658 
8. Schorpp, R. (2016). Greece \& Germany: What Role for Civil Society? Workshop III of the Greek-German Youth Congress. Political foundation "The Konrad-Adenauer-Stiftung". Retrieved July 25, 2021, from http://www.kas.de/wf/en/33.35961

9. Briushkova, N. O., Nikoliuk, O. V., \& Dobrianska, N. A. (2021). Institutionalization of the relationship between government and civil society in the context of management decisions. Ekonomika: realii chasu, (1(53)), $20-26$. Retrieved July 25, 2021, from https://economics.opu.ua/files/archive/2021/No1/20.pdf. doi: 10.5281/zenodo.4885297.

10. Briushkova, N. O., Nikoliuk, O. V., \& Udovytsia, O. F. (2020). Osoblyvosti pryiniattia upravlinskykh rishen v publichnomu upravlinni. Derzhavne upravlinnia: udoskonalennia ta rozvytok, (3). Retrieved July 25, 2021, from http://www.dy.nayka.com.ua/?op=1\&z=1605. doi: 10.32702/2307-2156-2020.3.39

Received 10 August 2021

Approved 24 August 2021

Available in Internet 24.10.21

Цитування згідно ДСТУ 8302:2015

Ніколюк О.В., Бондар В.А., Цвєткова Н.Ю. Напрями удосконалення системи публічного управління розвитком у сфері охорони здоров’я України // Економіка харчової промисловості. 2021. Т.13, вип. 3. С.94-100. doi: 10.15673/fie.v13i3.2137

Cite as APA style citation

Nikoliuk, O., Bondar, V., \& Tsvetkova, N. (2021). Directions of improvement of the system of public management of healthcare development of Ukraine. Food Industry Economics, 13(3), 94-100. doi: 10.15673/fie.v13i3.2137 